\title{
Tradição oral, construção de diálogo e conhecimento na comunidade quilombola da Rasa
}

\author{
ANA CAROLINA DE SOUSA VAZ \\ UNIVERSIDADE ESTADUAL DO NORTE FLUMINENSE DARCY RIBEIRO (UENF), CAMPOS DOS GOYTACAZES/RJ, BRASIL \\ HTTPS://ORCID.ORG/OOO0-0003-4399-5629
}

LILIAN SAGIO CEZAR

UNIVERSIDADE ESTADUAL DO NORTE FLUMINENSE DARCY RIBEIRO (UENF), CAMPOS DOS GOYTACAZES/RJ, BRASIL HTTP://ORCID.ORG/0000-000I-8737-9946

\section{Introdução}

Tendo como ponto de partida os campos da Pedagogia e da Antropologia, o presente artigo resulta de um estudo de caso que tematiza as ações de educação formal dedicadas à História e Cultura Afro-Brasileira e Indígena em uma escola pública municipal localizada na comunidade remanescente de quilombo da Rasa, na cidade de Armação dos Búzios, Rio de Janeiro. A pesquisa foi realizada durante o ano letivo de 2019, no período de fevereiro a dezembro, envolvendo entrevistas semiestruturadas e abertas, realizadas com professoras(es), gestoras(es) escolares e familiares de alunas(os) que são quilombolas e um estudo de caso de cunho etnográfico, com observação sistemática da prática pedagógica de uma docente que culminou com a montagem de uma feira literária.

Neste artigo, elegemos descrever e analisar as ações desenvolvidas e protagonizadas por uma professora com as(os) alunas(os) e a comunidade para compreender as potencialidades e os desafios da abordagem dos conteúdos previstos nas Leis 10.639/2003 e 11.645/2008, as quais alteraram o Artigo 26A da Lei de Diretrizes e Bases da Educação Nacional (LDBN), tornando obrigatório o ensino da História e Cultura Afro-Brasileira e Indígena nas escolas de ensino fundamental e médio, tanto da rede pública quanto da rede privada. O Art. 26-A preconiza que: 
Nos estabelecimentos de ensino fundamental e médio, oficiais e particulares, torna-se obrigatório o ensino sobre História e Cultura AfroBrasileira.

$\S 1^{\circ} \mathrm{O}$ conteúdo programático a que se refere o caput deste artigo incluirá o estudo da História da África e dos Africanos, a luta dos negros no Brasil, a cultura negra brasileira e o negro na formação da sociedade nacional, resgatando a contribuição do povo negro nas áreas social, econômica e política pertinentes à História do Brasil.

$\S 2$ O Os conteúdos referentes à História e Cultura Afro-Brasileira serão ministrados no âmbito de todo o currículo escolar, em especial nas áreas de Educação Artística e de Literatura e História Brasileiras (Brasil, 2003a).

Nosso artigo inicialmente aborda as políticas de reconhecimento das comunidades remanescentes de quilombo e a história do quilombo da Rasa, contrastada às políticas educacionais implantadas nas escolas municipais de Armação dos Búzios. Em seguida, descreve um projeto pedagógico desenvolvido por meio da construção de diálogos e conhecimentos entre professora, alunos(as) e lideranças, pautadas nas expressões culturais e na tradição oral do próprio grupo. $\mathrm{O}$ enfoque nos conteúdos da história e cultura africana, afro-brasileira e indígena permitiu à docente contextualizar a história da comunidade quilombola da Rasa, seu patrimônio cultural imaterial e as memórias de suas anciãs, constituindo também uma forma de restituição e, principalmente, valorização (ainda que seletiva) de conhecimentos, estéticas e valores civilizacionais africanos e afro-brasileiros. Por fim, o trabalho analisa alguns dos desafios e potencialidades da aplicação do Artigo 26A da LDB a partir da perspectiva nativa.

Como questão de fundo, o artigo considera as situações de desigualdade e segregação étnico-racial vivenciadas por crianças e jovens quilombolas da Rasa. Segundo Vaz (2015), ao circularem pelos bairros de classe média ou alta e nas zonas turísticas da cidade de Armação dos Búzios, essa população se sente inferiorizada por sua condição social e/ou cor de pele, o que se conecta a um histórico preconceito velado e dissimulado pela sociedade brasileira. Nesse sentido, as propostas de educação tomadas como foco do artigo mantêm indelével compromisso político com a mudança desse quadro.

O termo "étnico" constitui conceito que permite analisar processos de construção da distinção entre dois sujeitos sociais. O primeiro tido como nacional, portador de plenos direitos de participação, reivindicação e manutenção da cidadania e da ordem moderno-ocidental. O segundo constituído por indivíduos tidos como étnicos, historicamente conhecidos como o(s) outro(s), que são todos aqueles que têm diuturnamente questionada a sua própria condição de existência na ordem moderno-ocidental. Conforme Maldonado-Torres (2016:77), os “étnicos são os outros, e estes outros não estão representados de forma equitativa nem na administração das instituições de poder, nem na cultura ou na produção do conhecimento, entre muitas outras áreas".

Historicamente, o racismo constitui ideologia que justifica, naturaliza e apazigua as históricas desigualdades hierárquicas, econômicas, sociais e educacionais decorrentes dos quatro séculos de escravidão no Brasil, sendo "um comportamento, uma ação resultante da aversão, por vezes, do ódio, em relação a pessoas que possuem um pertencimento social observável por meio de sinais, tais como a cor de pele, tipo de cabelo, formato dos olhos etc." (Munanga \& Gomes, 2006:179). O preconceito racial "é uma ideia preconcebida suspeita de intolerância e aversão de uma raça em relação a outra, sem razão 
objetiva ou refletida. Normalmente, o preconceito vem acompanhado de uma atitude discriminatória" (Munanga, 2005:188).

Crianças e jovens do Quilombo da Rasa sentem que os espaços do centro da cidade de Armação dos Búzios, seus arredores turísticos e seus respectivos equipamentos culturais, bens materiais e oportunidades de acesso lhes são negados. Mesmo a despeito de dispositivos legais que intencionam incluir discussões sobre as ações de educação formal dedicadas à História e Cultura Afro-Brasileira e Indígena, há um descompasso na efetivação dessas políticas de inclusão, que é observado diante do silêncio dos currículos escolares em relação às questões políticas, históricas, culturais e sociais que o preconceito étnico-racial e o racismo impõem e que estes alunos vivenciam em seus cotidianos. Diante disso, interessou-nos investigar projetos e trabalhos desenvolvidos por professoras(es) das escolas inseridas nessa comunidade que estivessem pautados em formas dialógicas de construção da identidade quilombola e, não menos importante, de combate ao racismo.

\section{O balneário e o quilombo}

Armação dos Búzios está localizada na Região dos Lagos, nas Baixadas Litorâneas do interior do Estado do Rio de Janeiro, possuindo, de acordo com o Instituto Brasileiro de Geografia e Estatística (IBGE), uma população estimada em 33.870 pessoas para o ano de 2019. Historicamente, o município conhecido internacionalmente como Búzios pertencia à cidade de Cabo Frio, tornando-se autônomo apenas em 1995. Até a primeira metade do século XX, Búzios era uma pequena e pacata vila de pescadores. De acordo com Accioli (2018:24), "os relatos sobre a chegada dos primeiros africanos na região de Búzios remontam ao período da pesca das baleias, no século XVIII”. Ainda segundo a autora:

\footnotetext{
Nas memórias locais, o Arpoador da Rasa, que foi o primeiro ponto de desembarque de africanos, era também aonde os velhos sentavam para rememorarem histórias do cativeiro. Nas proximidades, fica o Porto das Canoas, local de pesca usado pelos escravos e que, ainda hoje, abriga uma comunidade pesqueira tradicional. Igualmente importante na memória comunitária é a Ponta do Pai Vitório. Os relatos locais contam sobre um velho africano, Pai Vitório, que teria sobrevivido a um naufrágio e passado a viver naquele local (ibidem).
}

Estudos como o de Acciolli (2012) apontam que os desembarques clandestinos estavam ligados à Fazenda Campos Novos, construída pelos Jesuítas da Companhia de Jesus em 1617. De acordo com Almeida (2015:74), ela tinha "o objetivo de promover um maior controle dos povos indígenas na região, devido à preocupação com o constante desembarque de estrangeiros que negociavam pau-brasil com os índios que ali habitavam".

Após 1759, ano da expulsão dos Jesuítas do Brasil, foram criados o Diretório dos Índios e o regime dos Aldeamentos Régios que colocaram em prática, segundo Holanda (1960), uma política que proibiu nos aldeamentos o uso de qualquer outra língua diferente do Português, a prática de se viver em habitações coletivas e da nudez. Institui-se a obrigatoriedade da criação de escolas nos aldeamentos e os índios que ali viviam foram obrigados a adotar o uso de sobrenome português, além de serem incen- 
tivados à mestiçagem e ao trabalho a partir da lógica de proteção do território contra os estrangeiros e produção extrativista e mercantilista. Essas políticas representaram para os índios parte do processo de espoliação de seus próprios territórios ancestrais, o desrespeito, negação e invisibilização das específicas etnicidades e a constante ameaça física de todos aqueles que se negaram a aceitar a imposição dessa política, culminando na expulsão territorial, guerras e massacres dessa população ao longo de cinco séculos. Com a expulsão dos padres, a fazenda foi encampada pelo Governo Real, colocada em leilão e arrematada por Manuel Pereira Gonçalves. Pessoas escravizadas serviram de mão de obra nas plantações de lavouras da fazenda, voltadas para o abastecimento da cidade do Rio de Janeiro.

Posteriormente a publicação da Lei de 7 de novembro de 1831, que declarou "livres" todos os escravos vindos de fora do Império e estabeleceu penas aos importadores, a região da Fazenda Campos Novos e as novas propriedades surgidas em seu território foram usadas para apoio ao tráfico clandestino. As características das praias localizadas na Rasa, com baías isoladas, permitiram que, no século XIX, fosse montada importante rota ilícita, utilizada como um dos últimos pontos clandestinos de pessoas escravizadas na região do antigo Cabo Frio (Accioli, 2018:26).

No caso específico da Rasa, após 1888, com a abolição da escravatura, boa parte das famílias que tinham sido escravizadas continuaram trabalhando para os grandes fazendeiros locais e também passaram a fazer uso das terras contíguas à praia, para desenvolver roças de mandioca e milho, a criação de pequenos animais e também a prática da pesca artesanal realizada a partir de linha mão, com o emprego de canoas feitas de tronco de árvores da Mata Atlântica (Xavier, 2006). São essas famílias que paulatinamente vão sendo expulsas dos latifúndios locais, vendo-se obrigadas a trabalhar nas salinas da região, na construção civil ou em serviços domésticos (Accioli, 2018). Muitas delas construíram casas de pau a pique junto às respectivas roças.

Apesar de estar a aproximadamente $12 \mathrm{~km}$ do centro da cidade, os moradores da Rasa historicamente sofreram e testemunharam formas violentas de expulsão territorial. Conforme narram seus moradores, isso gerou o paulatino desmembramento daquilo que se conhecia como Praia Rasa - e que abarcava também as comunidades quilombolas de Baía Formosa e Maria Joaquina -, a partir de intensa pressão imobiliária imposta pela ação de mandatários locais, do Estado e de construtoras, do forte investimento em hotelaria e da supervalorização dos terrenos em Búzios.

Em consequência direta das ações de empreendimentos imobiliários, na década de 1950, foi inaugurada a Avenida José Bento Ribeiro Dantas, que gerou grande número de novos loteamentos para a construção de residências, em especial, as de veraneio. Essa avenida de longa extensão foi construída, em grande medida, sobre terras onde historicamente vivia a comunidade negra da praia da Rasa, cujos moradores sofreram diretamente as consequências negativas e os impactos da abertura dessa via e das ruas subjacentes que impuseram ao seu território características urbanas, além do aumento do trânsito de pessoas e automóveis. A inauguração da Ponte Rio-Niterói, em 1974, ampliou o fluxo turístico vindo da capital em direção a toda região dos Lagos e com ele, a pressão e os conflitos por terrenos próximos à orla marítima, o que não seria diferente na praia Rasa, onde foi instalada uma marina com ancoradouro para lanchas, iates e barcos de veraneio. 
A partir da emancipação, em 1995, Búzios experimentou um novo boom de crescimento, em geral, desordenado (Spillman, 2010). Intervenções de caráter especulativo, realizadas sem a devida atenção ao patrimônio natural e material acarretaram diversas consequências sociais, econômicas, políticas e ambientais. Esse incremento "desenvolvimentista" trouxe consigo, também sem medidas de controle, a aquisição de casas de pescadores, bem como o estabelecimento de numerosas pousadas, restaurantes e bares.

\section{Reconhecimento identitário da comunidade quilombola e as políticas educacionais}

As políticas de reconhecimento quilombola são fruto de históricas e intensas mobilização e reivindicação de movimentos sociais negros. Constituem aparatos legais que visam a criar e instrumentalizar políticas de reparação étnico-racial, além de reconhecimento e valorização de grupos que passaram legalmente a se entender e a serem assim considerados como remanescentes das comunidades dos quilombos. Com direito à titulação das terras por eles habitadas, tiveram acesso a outras políticas que objetivam garantir direitos essenciais como educação, saúde, moradia, saneamento básico, segurança alimentar, cultura, etc.

Segundo Leite (2000), O’Dwyer (2007) e Arruti (2017) o termo "quilombo" vem sendo ressemantizado e ampliado, não só para abarcar aspectos históricos de organização coletiva e resistência do campesinato negro, contrapostos tanto ao histórico processo de escravização, quanto à expropriação e expulsão de famílias negras das terras onde vivem. Essa recriação acontece, principalmente, para privilegiar a concepção de "coletividade" enquanto marcador "que efetivamente conduz ao reconhecimento de um direito que foi desconsiderado, de um esforço sem reconhecimento ou resultado, de um lugar tomado pela força e pela violência" (Leite, 2000:352).

O conceito de "remanescentes das comunidades dos quilombos" emerge do Art. 68 do Ato das Disposições Constitucionais Transitórias (ADCT) da Constituição Federal de 1988. Somente com o Decreto 4.887 de 2003 é que se regulamenta quem são os sujeitos desse direito, os critérios de reconhecimento das comunidades e das terras quilombolas:

Art. $2^{\circ}$ Consideram-se remanescentes das comunidades dos quilombos, para os fins deste Decreto, os grupos étnico-raciais, segundo critérios de auto-atribuição, com trajetória histórica própria, dotados de relações territoriais específicas, com presunção de ancestralidade negra relacionada com a resistência à opressão histórica sofrida.

\$1ํ-Para os fins deste Decreto, a caracterização dos remanescentes das comunidades dos quilombos será atestada mediante autodefinição da própria comunidade.

$\$ 2$ São terras ocupadas por remanescentes das comunidades dos quilombos as utilizadas para a garantia de sua reprodução física, social, econômica e cultural.

CAMPOS V.22 N.1 p. 159-183 jan.jun.2021 163 
$\$ 3$ Para a medição e demarcação das terras, serão levados em consideração critérios de territorialidade indicados pelos remanescentes das comunidades dos quilombos, sendo facultado à comunidade interessada apresentar as peças técnicas para a instrução procedimental.

$\mathrm{Na}$ Rasa, as desapropriações e expulsões decorrentes da forte pressão imobiliária desencadearam intenso processo político de organização e reivindicação de direitos que, em 2005, levaram 422 famílias a pleitear e obter o reconhecimento, perante a Fundação Palmares, da titulação de Comunidade Remanescente de Quilombo da Rasa. O Relatório Técnico de Identificação e Delimitação foi aprovado pelo Comitê de Decisão Regional do Instituto Nacional de Colonização e Reforma Agrária (Incra/ RJ) em 16 de maio de 2017 e contempla estudos socioeconômicos, culturais, antropológicos, fundiários, cartográficos e ambientais relacionados ao território da comunidade. Os estudos apontaram para a comunidade quilombola da Rasa uma área delimitada de 109,7 hectares. A regularização fundiária foi tornada pública em portaria publicada no Diário Oficial da União no dia 27 de junho de 2017.

O bairro da Rasa possui nove escolas municipais que atendem, aproximadamente, a 3.300 alunas(os) da Educação Infantil. Nenhuma dessas escolas foi integrada à Política de Educação Escolar Quilombola, prevista no Programa Brasil Quilombola ${ }^{1}$, nem quando essa era de responsabilidade da Secretaria de Educação Continuada, Alfabetização, Diversidade e Inclusão (SECADI) - secretaria específica do Ministério da Educação (MEC) -, nem depois de sua substituição pela Diretoria de Políticas para Modalidades Especializadas de Educação e Tradições Culturais Brasileiras (criada pelo Decreto $n^{\circ} 9.465$, de 2 de janeiro de 2019, que alterou profundamente a estrutura do MEC). Em termos gerais, essa falta de acesso à garantia e aplicação das políticas sociais que são de direito nas comunidades quilombolas permanece sendo um desafio a ser vencido.

De acordo com o coordenador da pasta de Etnia e Gênero da Secretaria Municipal de Educação, Ciência e Tecnologia (doravante, SMECT) de Armação dos Búzios, a efetivação da Educação Escolar Quilombola está “dentro da grade”, podendo ser implementada nos próximos anos. Entretanto, atualmente, ainda não há o delineamento de ações que busquem assegurar o atendimento educacional diferenciado às comunidades quilombolas do município e o desenvolvimento de uma legislação específica. Segundo a legislação vigente,

A Educação Escolar Quilombola é desenvolvida em unidades educacionais inscritas em suas terras
e cultura, requerendo pedagogia própria em respeito à especificidade étnico-cultural de cada co-
munidade e formação específica de seu quadro docente, observados os princípios constitucionais,
a base nacional comum e os princípios que orientam a Educação Básica brasileira. Na estruturação
e no funcionamento das escolas quilombolas, deve ser reconhecida e valorizada sua diversidade
cultural (Brasil, 2010a:42).

O Art. 9 da Resolução n 8/2012 aponta, por sua vez, que a Educação Escolar Quilombola compreende tanto as escolas quilombolas, quanto as que atendem estudantes oriundos de territórios quilombolas. Por não haver a implementação da legislação específica para a educação quilombola nas

1 Plano lançado em 2004 que constitui um dos pilares da Agenda Social Quilombola (Decreto 6.261/2007), articulando quatro eixos de ação: acesso à terra; infraestrutura e qualidade de vida; inclusão produtiva e desenvolvimento local; direitos e cidadania. 
escolas localizadas na comunidade da Rasa, podemos afirmar que não é assegurado acesso à alimentação e infraestrutura escolar que respeite a cultura do grupo, assim como observe o cuidado com o meio ambiente e a geografia local. Também não há a promoção de uma formação específica e diferenciada (inicial e continuada) aos profissionais das escolas localizadas nesse território, nem é garantido que a atividade docente seja exercida preferencialmente por professoras(es) oriundos de comunidades quilombolas. Tampouco é assegurado o desenvolvimento de um currículo escolar que tenha referência na cultura, na tradição, na oralidade e na memória do grupo.

As consequências da não efetivação da Educação Escolar Quilombola nas escolas da comunidade se estendem para outros âmbitos. Essa política social deveria se articular em rede a outras ações públicas focalizadas na expansão e no fortalecimento da participação dos próprios agricultores(as) familiares quilombolas nos mercados institucionais do município, bem como no estímulo às ações pautadas na agrobiodiversidade e no desenvolvimento sustentável local, enquanto alternativa viável para a manutenção econômica e circulação de dinheiro na comunidade.

\section{Prática pedagógica e construção de conhecimento na comunidade Quilombola da Rasa}

Armação dos Búzios possui 23 escolas municipais que abrangem da Educação Infantil ao Ensino Médio. Bianca ${ }^{2}$ leciona na escola que possui o maior número de alunos matriculados na Comunidade Remanescente de Quilombo da Rasa, atendendo, aproximadamente, 700 alunos da Educação Infantil e dos anos iniciais do Ensino Fundamental $\left(1^{\circ}\right.$ ao $\left.5^{\circ}\right)$. O quadro de funcionários é composto por 113 profissionais, sendo 63 professoras(es). Destes, a maioria não reside no município de Búzios.

As(os) professoras(es) distribuem-se em: Regente 1; Regente 2; Arte e Cultura; Educação Física. Docentes que atuam como Regente 1 lecionam as disciplinas de Língua Portuguesa, História e Geografia; já Regentes 2 ministram aulas de Matemática e Ciências. O ensino de História e Cultura Afro-brasileira e Indígena, de acordo com o Regimento Escolar da cidade de Armação dos Búzios, deve ser desenvolvido nas disciplinas de História, Língua Portuguesa e Arte e Cultura, em consonância com o Artigo 26A da LDBN.

Em 2019, Bianca - que tem a Formação de Professores na Modalidade Normal em Nível Médio - atuou como Regente $1 \mathrm{em}$ uma turma de $5^{\circ}$ ano. Ela exercia a função de professora há 6 anos e, nesse período, sempre atuou no bairro da Rasa. A escolha por trabalhar ali se relaciona a seu matrimônio, pois, segundo ela, seu esposo "tem muito conhecimento aqui, com as pessoas daqui, então eu escolhi trabalhar aqui”. Seu cônjuge pertence a uma das principais famílias quilombolas da Rasa e, por este motivo, há nove anos Bianca passou a morar na cidade de Búzios, justamente no bairro da Rasa.

2 Os nomes utilizados são fictícios, com exceção a D. Uia e D. Eva, anciãs e mestras do quilombo da Rasa. D. Uia veio a falecer no dia 10/06/2020, aos 79 anos de idade, vítima da Covid-19. Sua mãe, D. Eva, com 111, foi vacinada no dia 19/01/21. Nossas condolências a toda a comunidade, em especial à família de D. Eva e D. Uia, por essa inestimável perda. Que a força dessas duas mulheres negras em suas lutas cotidianas nos animem e nos inspirem a permanecer firmes contra toda a opressão e o desrespeito, construindo assim dias melhores e mais dignos, com vacina gratuita e de qualidade para todas as brasileiras e todos os brasileiros. 
A docente contou-nos que adquiriu o conhecimento sobre a formação do quilombo por meio das "histórias contadas pela avó e bisavó do meu esposo que faz parte do quilombo remanescente aqui. Pesquisas na internet, mas tem bem pouco ainda. E alguns vídeos também do YouTube" e que esse acesso às informações facilita o desenvolvimento do seu trabalho docente. Ou seja, por ter se casado com um membro da comunidade e se tornado moradora dela, a professora passou a ter acesso diferenciado à transmissão de saberes tradicionais pelos anciãos e, a partir disso, vem buscando se aproximar da dinâmica social e política ali vivenciada.

De acordo com Bianca, seu interesse e preocupação em promover a construção do diálogo a esse respeito na comunidade escolar surgiu por meio da observação das(os) alunas(os) e da detecção de que "não tinham esse conhecimento". Aproveitando a oportunidade de um evento literário fomentado pela SMECT, elaborou um projeto contemplando atividades de pesquisa de campo e aula passeio a serem realizadas por sua turma - o que, de acordo com Freinet (1966), visa a aproximar a prática educativa e o contexto social do alunado.

Entrevistas com os moradores mais velhos, feitas durante as aulas passeio, permitiram que as anciãs da comunidade, reconhecidas como mestras, fossem localizadas, ouvidas e tivessem suas falas registradas pelas(os) alunas(os). Essa estratégia possibilitou que docente e discentes trabalhassem detidamente sobre essas narrativas, destacando a importância da recordação e do compartilhamento dos saberes dos mais velhos para a própria valorização da história e cultura da comunidade. Os resultados desse projeto pedagógico e o trabalho de interlocução com a comunidade quilombola foram expostos durante o evento literário.

Eu acho que é uma cultura muito rica, uma história muito importante, que é desvalorizada pela própria comunidade. As crianças que moram aqui, que chegam no quinto ano, não conhecem a história da Rasa, não conhecem a história do bairro. O marco histórico que nós temos mais antigo, que é do negro ali no cruzeiro, as crianças não conhecem, não se apropriam desse conhecimento, dessa riqueza, que poderia abrir um leque cultural imenso para eles. Então, não se apropriam, é desvalorizada pela própria comunidade (Entrevista com a professora Bianca, 11/10/2019).

Tendo esses relatos ancestrais como fio condutor inicial foi possível à professora construir a abordagem da história de Búzios a partir de uma dupla perspectiva, a saber: (1) a narrativa oficial, fria e distante da vida cotidiana dos educandos e (2) a narrativa pautada nas recordações coletivas do quilombo. A primeira seria pautada em documentos históricos escritos e estatísticas, seguindo encadeamento lógico das relações econômicas, que têm como objetivo único o desenvolvimento regional e nacional. Geralmente, omite o fato de que, por estar subsidiada por textos escritos, conta uma única versão dos acontecimentos, em consonância com os interesses das pessoas letradas, notadamente homens brancos, pertencentes a classes abastadas. A segunda narrativa, por sua vez, vai privilegiar o passado marcado pela dominação e escravidão de indígenas e africanos, que justifica e naturaliza a imposição da apropriação do fruto de seus trabalhos; a lembrança dos desembarques de pessoas negras escravizadas na praia Rasa; o conhecimento sobre as condições lastimáveis em que essas pessoas chega- 
vam; as formas de resistências encontradas para a manutenção da vida na comunidade desde o período da escravidão até os dias de hoje.

Ao articular dialeticamente essas duas perspectivas, a professora buscou lidar com questões decorrentes das profundas desigualdades étnico-raciais, econômicas e sociais enfrentadas por estudantes e familiares em seu cotidiano na cidade, um dos principais destinos turísticos ${ }^{3}$ do Brasil.

[...] a cidade é referência mundialmente, em relação às praias. Essas crianças quase não vão às praias famosas, o que eles conhecem é o bairro local, o mangue de pedra, às vezes visitam para tomar um banho - mas não sabem a importância desse espaço. Visitam a praia Rasa de vez em quando, mas muito de vez em quando, porque é uma praia suja. Então, assim, Búzios para eles é dividido. Dividem em: Rasa é uma coisa e Búzios é outra, como se fosse algo muito além do que podem alcançar. As famílias são grandes, não tem como pagar passagem para todos irem à praia e aí eles acham que Búzios é a cidade dos ricos e eles moram no "sub-bairro" Rasa, que é a cidade dos pobres. Eles são pobres e é o que é de direito deles (Entrevista com a professora Bianca, 29/11/ 2019).

A partir da fala de Bianca podemos compreender que o racismo na cidade de Búzios, como em todo o Brasil, constrói barreiras simbólicas que, nesse caso, acabam demarcando geograficamente muros invisíveis e acesso segregado entre brancos e negros na cidade. Segundo a professora, isso se reflete no ir e vir das próprias crianças, jovens e seus familiares, que quase não percorrem outras localidades além da Rasa. Assim, tais estudantes vivem em uma cidade litorânea, internacionalmente reconhecida por seus atrativos naturais tidos como paradisíacos, mas quase não vão às praias, nem aos estabelecimentos comerciais e equipamentos culturais localizados na área central, por serem pobres e negros.

Esse cenário se complexifica ainda mais em decorrência da onda migratória de latino-americanos, em especial de argentinos que, a partir dos anos 1970, escolheram o pequeno vilarejo de pescadores para morar, em busca de oportunidades de investimento em empreendimentos turísticos, tentando conciliar trabalho e qualidade de vida ante à crise econômica no seu país de origem. O reflexo desse afluxo, que se estende até os dias de hoje, traduz-se na internacionalização do turismo de Búzios, cuja indústria confere preferência a pessoas brancas que dominem a fala de diferentes idiomas, especialmente o espanhol e o inglês. Elas ocupam vagas de trabalho em bares, restaurantes, quiosques de praias, lojas de grife, setores que oferecem as melhores oportunidades de renda na cidade.

A compreensão de que uma maior visibilização e valorização da comunidade quilombola, em sua especificidade, é importante para romper as barreiras de segregação étnico-raciais está na base da iniciativa de Bianca. A partir da possibilidade aberta pela Festa Literária, a professora promoveu ações de educação antirracista dentro e fora da escola. Algumas questões estruturais se impõem ao processo. Exatamente pelo fato de a escola estar localizada em uma comunidade quilombola, Bianca compreendeu a necessidade de ampliar o trabalho pedagógico com temáticas referentes à história e cultura local. A docente as considera fundamentais na construção da identidade e do sentimento de pertencimento de alunas(os), bem como para a valorização da memória coletiva e do próprio território. Porém, esse

3 Em 1964 o balneário recebeu a visita da atriz francesa Brigitte Bardot, expoente do cinema internacional e símbolo de beleza e apelo sexual. Com seu reconhecimento internacional, acabou sendo pivô da publicização turística da localidade, atraindo visitantes estrangeiros. Na década de 1970, a construção da Ponte Rio-Niterói facilitou o acesso às praias da Região dos Lagos, ampliando tanto o apelo e atração de turistas para o local como a decorrente pressão imobiliária para atendimento desta demanda. 
esforço não é acompanhado e nem se projeta a partir de intervenções públicas estruturantes específicas, como poderia acontecer se as instituições de ensino locais estivessem integradas à Política de Educação Escolar Quilombola. Isso não diminui a importância das ações de Bianca, mas explica suas angústias frente às dificuldades encontradas para abordar temáticas relativas à diversidade cultural, em especial os conhecimentos afro-brasileiros específicos desse grupo.

\section{Expressões culturais e tradição oral na Festa Literária de Búzios}

A Festa Literária - "Búzios Palavra que encanta”, lançada pela SMECT, teve a participação de todas as escolas municipais. De acordo com documento oficial, o evento almejava a "valorização da nossa gente, buscando desta forma resgatar e consolidar a identidade do alunado como buziano" (Projeto da Festa Literária Búzios Palavra que Encanta, 2019b). A oportunidade de participar da Festa Literária permitiu que Bianca elaborasse estratégias para, a partir da memória da comunidade quilombola, visibilizar esses conhecimentos enquanto saberes específicos, pautados nas tradições orais afro-brasileiras e, concomitantemente, como legítima forma de resistência, resiliência e base para a criatividade dessas(os) alunas(os). Assim, ela pôde estabelecer relação entre os conteúdos propostos pelos currículos de Língua Portuguesa, História e Geografia do $5^{\circ}$ ano do Ensino Fundamental (Referencial Curricular de Armação dos Búzios, 2019a) que, em linhas gerais, devem abordar as seguintes competências:

Compreender a língua como fenômeno cultural, histórico, social, variável, heterogêneo e sensível aos contextos de uso, reconhecendo-a como meio de construção de identidades de seus usuários e da comunidade a que pertencem.

Compreender acontecimentos históricos, relações de poder e processos e mecanismos de transformação e manutenção das estruturas sociais, políticas, econômicas e culturais ao longo do tempo e em diferentes espaços para analisar, posicionar-se e intervir no mundo contemporâneo.

Estabelecer conexões entre diferentes temas do conhecimento geográfico, reconhecendo a importância dos objetos técnicos para a compreensão das formas como os seres humanos fazem uso dos recursos da natureza ao longo da história (Referencial Curricular de Armação dos Búzios, 2019a).

Esse planejamento permitiu que a professora e sua turma participassem da Festa Literária expondo o resultado dessa atividade feita a partir das experiências socioculturais vividas pelas(os) alunas(os) e suas famílias e registradas sistematicamente durante a realização do projeto.

[...] o município trabalhou: "Búzios, palavra que encanta". E aí quando fala de Búzios muita gente só vê a Rua das Pedras, Brigitte Bardot. Eu quis trazer a identidade do bairro, da história local, porque... para as crianças perceberem que o bairro da Rasa sofreu uma mudança muito rápida. A minha sogra tem 46 anos. Quando ela era criança não tinha prato para ela se alimentar. Ela falou que pegava uma lata de metal, socava com um piláo que eles faziam, tipo um socador de alho. So- 
cavam aquela lata, deixavam no sol para secar, porque geralmente era uma lata de agrotóxico que os fazendeiros usavam nas plantações. Então, depois essa comunidade que não tinha meios para adquirir um prato e um copo, pegava esse alumínio e transformava em prato, em copo. As casas eram de barro. Ela falava que mesmo o chão de terra batida, limpavam com umas vassouras de piaçava - que era uma plantinha que tinha aqui. Então, assim, ela tem 46 anos, ela viveu essa infância e hoje ela usufrui de uma coisa totalmente diferente. Tem uma casa totalmente diferente, com um conforto que ela nunca imaginou quando era criança. Eu falei com os meus alunos, as crianças não iam para a escola, às vezes iam, mas a escola era em Campos Novos. Então eles tinham que acordar de madrugada, andar horas até chegar na escola. Quando os pais iam pescar, as mães ficavam para plantar. Era uma plantação de subsistência. Se não planta, não come. E as crianças ajudavam as mães nessa colheita. Era assim, o trabalho vinha em primeiro lugar. A escola? Ninguém sabia ler e escrever. A prioridade era a alimentação. Então tinha a casa de farinha onde transformavam a mandioca na farinha e aí os moradores mais antigos contam que era uma fonte de muita alegria essa transformação, porque com a farinha eles podiam cozinhar coisas muito diferentes. Era uma festa. A noite depois que produziam a farinha, todos se reuniam, faziam uma festa, uma fogueira, assavam legumes. Então, as pequenas coisas que conseguiam era motivo de grande alegria na comunidade (Entrevista com a professora Bianca, 29/11/2019).

A docente reconhece a importância da valorização da tradição oral, enquanto processo que articula identidades e aprendizagens. Para Bianca, mais do que simplesmente ouvir uma história, o contato com as narrativas dos mais velhos significa a transmissão de experiências ancestrais que contribuem na manutenção da identidade, da memória e da cultura desta comunidade 4 .

A tradição oral constitui matriz cultural presente em grupos que não se pautam na escrita para o acúmulo, a manutenção e a transmissão de conhecimentos entre gerações, como são os casos de sociedades africanas, afro-brasileiras e ameríndias. Essa prática também pode estar intimamente ligada à noção de memória social e performance, que se desenvolvem por meio da corporalidade e musicalidade, uma vez que esses saberes são incorporados em processo mnemônicos, os quais dependem do embalo, enquanto movimento ritmicamente ordenado do corpo, para que a rememoração e presentificação da palavra versada aconteça.

Halbwachs (1990) conceituou a memória coletiva como processo de escolha de certos elementos do passado para construir uma narrativa a partir do presente. Ela está sempre encarnada num grupo, que pode ser efêmero ou estruturado, sendo o vínculo entre seus integrantes fundamental para a sua existência e manutenção. Por grupo, o autor compreende não um conjunto de indivíduos definidos, mas aquilo que o constitui em sua estabilidade e permanência, ou seja, essencialmente, uma ordem de ideias, preocupações e interesses que se particulariza e se reflete nas personalidades de seus membros, bem como que subsiste de modo que qualquer um deles possa acessá-la no futuro, bastando para isso recolocar-se nessa corrente da qual fez parte um dia ou não. Sob essa luz, os processos de reconstrução de religiões e cultura afro-brasileiras foram explicados a partir da conservação de fragmentos de lem-

4 Segundo Prandi (2000:50), "é natural do ser humano a busca pela identificação de um grupo social, o indivíduo recorre a lembranças de lugares e objetos, presentes nas memórias e assim organiza seus referenciais identitários, pois a identidade é percebida, captada e construída e está em permanente transformação". 
branças mantidas e recriadas por meio da memória coletiva de diferentes grupos de pessoas escravizadas e de seus descendentes (Bastide, 1960).

As culturas, enquanto processo e acontecimento, se desenrolam a partir do mundo da vida, no tempo presente e, por isso, possuem caráter de constante (re)elaboração que permite a cada uma selecionar, a partir de suas respectivas epistemologias e modos de vida, formas distintas de lidar com o espaço, o tempo, a acumulação e transmissão de saberes, fazeres, memórias e bens, processos esses que engendram a própria reprodução social do grupo e sua inerente transformação histórica. Segundo Gusmão (1999:46):

a cultura e seu movimento incorpora ainda uma outra dimensão que é seu caráter de mediação, ou seja, aquilo que faz com que as condições objetivas de vida sejam expressas pelos sujeitos sociais, não pelo que de fato são e representam, mas pela forma pela qual o real é significado, percebido e interpretado. Cabe aos indivíduos e grupos, perceber, significar e interpretar a si mesmos em relação ao que vivem e experimentam e que, impregnam a textura social do cotidiano, enquanto imagem, rotina e ruptura, enquanto universo significante que é parte da vida vivida, pensada, sentida e concebida.

Por meio da fala, da gestualidade e das expressões musicais, os saberes afro-brasileiros têm sido transmitidos de geração em geração, permitindo o contato do passado com a vivência do presente num movimento dialético entre resistência e transformação, na busca incessante pela permanência dos seus valores ancestrais e pela garantia dos seus direitos. Segundo Ingold (2000) e Carneiro da Cunha \& Almeida (2001), os conhecimentos tradicionais são repertórios cognitivos construídos e transmitidos que têm como substratos sentimentos, sensibilidades, habilidades e orientações geradas a partir de longa experiência no ambiente particularmente habitado. Os saberes e fazeres tradicionais são expressões culturais que, apesar de terem sido (re)elaborados a partir das práticas eficientes de como lidar com desafios, contingências e oportunidades do cotidiano, não possuem caráter extraordinário ou espetacular.

Compreender a validade e a importância das expressões e tradições orais para a valorização da história e da cultura da população negra pode romper com processos de exclusão, discriminação e preconceitos que frequentemente são detectados nos ambientes escolares e fora deles. Esse reconhecimento não significa a desvalorização dos conhecimentos advindos e produzidos pela escrita, nem tampouco significa dizer que essa população não apresenta habilidades para a escrita. Hampaté Bâ (2010:167-168) destaca que, nas nações modernas, onde o livro é considerado o principal veículo de herança cultural, durante muito tempo julgou-se que os povos sem escrita eram sem cultura. Com o trabalho realizado por etnólogos do mundo inteiro, esse conceito infundado desmoronou.

Podemos argumentar que Bianca desempenha ação de ser professora-pesquisadora e, a partir da leitura crítica do mundo envolvente, passa a perceber a necessidade de realizar ações pedagógicas

$5 \mathrm{O}$ conceito de cultura não diz somente respeito aos traços, costumes, festas e crenças de um povo mas, de forma ampliada, "denota um padrão de significados transmitidos historicamente, incorporado em símbolos, um sistema de concepções herdadas, expressas em formas simbólicas por meio dos quais os homens comunicam, perpetuam e desenvolvem seu conhecimento e suas atividades em relação à vida" (Geertz, 1989:103). Essa ampliação conceitual permite compreender que não existe cultura no singular e as discussões sobre etnicidade são importantes pois passam a produzir e reproduzir fronteiras de diferenciação entre culturas (Barth, 1998). 
que focalizem as expressões culturais, buscando meios para transformar e ressignificar um contexto de racismo e exclusão étnico-racial. Ela entende que as memórias e os conhecimentos tradicionais da comunidade quilombola da Rasa, geralmente transmitidos por meio da oralidade, constituem meio de construção e afirmação dessa identidade. Esses saberes se remetem a uma África ancestral enquanto fonte e inspiração matricial ${ }^{6}$.

Durante as aulas, Bianca observou que as(os) alunas(os) estavam expostos, desde a mais tenra idade, a situações de conflitos e de racismo, sendo esses sentimentos introjetados enquanto parte constituinte de sua identidade. As ações pedagógicas desenvolvidas pela docente recorreram, assim, à escuta estudantil. A partir do acolhimento em sala de aula para temáticas tão sensíveis, a turma foi convidada a escutar as histórias de vida de moradores da comunidade - o que, de acordo com Reis (2017:24), é indispensável para a formação da identidade negra.

No caso da comunidade da Rasa, os princípios, valores e concepções da tradição oral influenciam nos processos de ensinar e de aprender também dentro do espaço escolar, como destacado por Bianca:

[as(os) alunas(os)] trouxeram pesquisas de lendas locais. Falaram de saci-pererê, mula-sem-cabeça, que os avós, os tios afirmam até hoje que viam esses seres quando eram crianças, que tinha isso sim. E alguns mais velhos contam que quando começou, trouxeram a igreja Assembleia de Deus para o bairro da Rasa, essas aparições foram desaparecendo aos poucos. É interessante porque traz uma memória cultural e uma verdade própria da comunidade. Hoje as crianças sabem que não é verdade, mas naquele tempo era passado de geração para geração (Entrevista com a professora Bianca, 29/11/2019).

A partir desse relato compreendemos que a presença e atuação de igrejas neopentecostais vêm promovendo a ressignificação, o combate e a interdição da agência de conhecimentos, mitos e narrativas de matriz africana na comunidade. A diversificação do campo religioso local altera também a disposição das famílias em transmitir tais conhecimentos, afirmando que seriam coisas do passado ou agências a serem vencidas. Dito de outra forma, o neopentecostalismo, ao propor o ataque sistemático às religiões e expressões culturais afro-brasileiras (Silva, 2007), produz uma espécie de silenciamento e interdição da transmissão de conhecimentos tradicionais afrodiaspóricos, que geralmente acontecem por meio tanto das práticas cotidianas, quanto das redes de produção e celebração de rituais e festividades dos próprios grupos.

\section{Promoção de diálogo entre saberes na escola}

Ao longo de cinco meses, Bianca propôs atividades dentro e fora da escola, envolvendo também os responsáveis pelo alunado, seus familiares e membros da própria comunidade quilombola.

6 Isso se conecta ao que Rocha (2011:32-33) comenta: "É preciso esclarecer que as sociedades africanas consideradas tradicionais são aquelas que souberam conservar princípios e valores que eram cultivados anteriormente à invasão do continente africano pelos europeus. Já as comunidades tradicionais afro-brasileiras são aquelas que, pelo suporte da oralidade, preservaram em sua memória coletiva os valores tradicionais africanos, recriados e reatualizados em terras brasileiras. Por isso, as marcas da cultura africana, indiscutivelmente impregnadas no cotidiano da sociedade brasileira, precisam ser mais estudadas e entendidas, especialmente as manifestações da tradição oral, que, de forma incisiva, foram ressemantizadas e reconstruídas nas comunidades tradicionais afro-brasileiras”. 
Esse projeto foi apoiado e acompanhado por Luana, supervisora escolar que auxiliou tanto Bianca, como a equipe docente, com subsídios bibliográficos e metodológicos. Com isso, Luana esperava aumentar o engajamento de docentes e estudantes, tendo como efeito a promoção de reflexões sobre as especificidades e lutas da comunidade quilombola frente às mudanças ocorridas no bairro em trinta anos, período que compreende o processo de emancipação e expansão do município. A esse respeito, a supervisora comentou:

Durante todo o nosso semestre agora, a partir... depois das férias, nós começamos a fazer várias atividades de campo para que eles pudessem entrevistar pessoas da Rasa, moradores da Rasa, para que eles pudessem conhecer o comércio da Rasa agora, o comércio da Rasa anterior e a Rasa antes de ser Rasa. Então nós fizemos visitas na casa da [liderança na comunidade], que é a casa da [liderança na comunidade] também, da comunidade... Eles tiveram uma contação de histórias lá, depois nós fomos caminhando pelo local, eles foram fazendo releituras, desenhos, informações. Depois nós elaboramos um questionário de entrevistas, eles levaram essa entrevista para casa, perguntaram para os pais, o que eles conheciam da Rasa, né? Fizeram toda uma história, uma contextualização. A partir dessa história, eles partiram para a prática, que foi a montagem de um teatro, onde eles representavam a Rasa há 30 anos atrás, que é bem diferente dos dias de hoje e agora eles estão expondo todos os trabalhos que eles construíram. Além de ter trabalhos de exposição deles, eles conseguiram materiais também que representam, né... a história da Rasa. Então, ao longo desse período todo, além de ir para a rua, para conhecer a história, eles iam também catar material reciclado, montar a sala, aí ficou bem bacana, valeu a pena (Entrevista com a supervisora escolar Luana, 31/10/2019).

O olhar de Bianca possibilitou uma nova concepção de desenvolvimento de ações pedagógicas, extramuros, viabilizando a construção de significados a partir do encontro com o Outro, sua própria história e cultura. Embora tenha buscado desenvolver esse novo olhar sobre a sua prática, Bianca considerava, no entanto, que a escola na qual atuava cumpria "o mínimo" referente ao Art. 26A da LDB. Diz ela:

Olha, acho que tem, o mínimo sim. O potencial dela é muito grande, então, tem potencial para estudar isso aí e muito mais. Até para quebrar certos preconceitos. Porque quando falam de índio, as crianças já remetem aquele que fica batendo tambor, com a boca, anda pelado no meio da floresta. Então, já que a gente tem um quilombo que sofreu influência indígena e é único por isso. Dentro de várias questões é um quilombo diferenciado porque sofreu essa influência, acho que a escola poderia trabalhar muito mais, mostrar que o índio não é só aquele que vive pelado no meio da floresta e trazer um pouco dessa cultura indígena de verdade para abrir um pouco a mente dessas crianças para enxergar um mundo de uma forma diferente. Não ficar aprisionado na caixinha achando que negro e africano tem que ser macumbeiro - nem sabe o que é, mas escuta falar - e o índio, aquele que anda pelado, mas não sei o que e só a religião que presta é a cristã. Eu sou cristã, mas eu quero que os alunos pensem, reflitam (Entrevista com a professora Bianca, 29/11/2019). 
Durante a aula passeio, as(os) alunas(os) saíram da escola juntamente com a docente e percorreram um caminho de aproximadamente $2 \mathrm{~km}$ com o transporte escolar até a casa onde vivem duas das principais lideranças da comunidade - uma delas, nascida em 3 de junho de 1941, bisneta de mulher escravizada e engajada enquanto principal liderança local na busca da regulamentação das terras de comunidades e pela garantia de políticas públicas para a população quilombola. O grupo também se encontrou com a eminente anciã da Rasa, de 110 anos, que nos recebeu em sua casa e nos contou ser neta de escravizados, criada na Fazenda Santo Inácio, em Campos Novos. Ao longo desse projeto as(os) alunas(os) tiveram a oportunidade de experienciar a condição de serem aprendizes dessas duas mestras, questionando, escutando e registrando os conhecimentos transmitidos por meio das memórias e narrativas das anciãs, enquanto expressão da tradição oral local.

As duas, mãe e filha narraram, a partir de experiências vivenciadas na Rasa, em seus respectivos tempos, como foram criadas e como criaram seus filhos pelo trabalho na roça de milho e mandioca, assim como por meio da pesca artesanal, que envolvia também limpar e salgar o peixe, pois naquela época não havia geladeira. Também contaram que, naquele tempo, só se cozinhava em fogão de lenha, que enfumaçava toda a cozinha e as crianças podiam brincar pelos matos, quintais e roças, que se estendiam por toda a extensão da Praia da Rasa, desde que trouxessem lenha pra acender e alimentar o fogo. A maioria das casas eram feitas de pau-a-pique. A turma ouviu com atenção e fez perguntas sobre a formação da comunidade da Rasa.

No caminho de retorno à unidade escolar, a professora foi chamando a atenção sobre a importância de conhecer e, ao mesmo tempo, de se questionar sobre o passado. Bianca destacou como as pessoas viviam, trabalhavam, se deslocavam e como essas ações configuraram o quilombo. Questionou ainda a turma sobre como cada um(a), seus familiares e vizinhos vivem hoje e quais são as ações que poderiam ser realizadas para a melhoria das condições de vida, tanto do quilombo, quanto do bairro, com o mesmo nome. Para isso, as(os) estudantes também foram estimulados a, posteriormente, realizar fotografias e anotações a partir das informações obtidas na visita e das questões que dali surgiram. Após discutir e refletir sobre a visitação e acerca dos registros textuais e imagéticos produzidos pela turma, a professora lhes entregou um questionário para que fizessem uma entrevista com seus próprios pais e responsáveis, em suas respectivas casas. A atividade visava à promoção do diálogo da família em torno da vivência na Rasa, tendo como marcação temporal os últimos 30 anos.

Com a transformação desse conjunto de informações em dados, as(os) alunas(os) tiveram a oportunidade de compreender a condução de uma pesquisa, que passou a ser o foco gerador de discussões e debates em classe. As narrativas das anciãs e as entrevistas realizadas com os familiares permitiram que fosse destacada a recorrência de memórias e vivências ocorridas em alguns espaços de sociabilidade e manutenção do grupo, com especial destaque para a pesca, a roça, a cozinha e a casa de farinha. Assim, esse processo permitiu a seleção de aspectos sobre o sustento e a forma de vida na Rasa, que foram usados como referência para a construção, por parte das(os) estudantes, de cenários que representaram espaços tidos como importantes tanto pelas mestras, quanto pelos familiares entrevistados.

Para essa montagem, foram selecionados e utilizados materiais reciclados, recolhidos pelas(os) alunas(os) em suas próprias casas. Ao final do ano letivo, em culminância com a Festa Literária, houve 
a montagem de uma exposição com cenários distintos, a saber: barco de pesca (Fig. 1); casa de farinha (Fig. 2); roçado da lavoura (Fig. 3); cozinha com fogão de lenha (Fig. 4); brinquedos e brincadeiras infantis (Fig. 5).

\section{Figura 1: Cenário que repre- senta barco e apetrecho de pesca.}

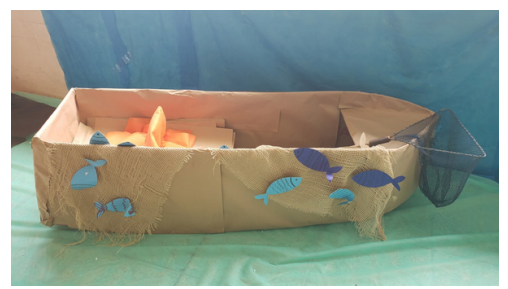

Fotografia: Ana Vaz, 29/11/2019.

\begin{abstract}
Figura 2: Cenário que representa a Casa de Farinha onde se realiza a produção artesanal de farinha de mandioca.
\end{abstract}

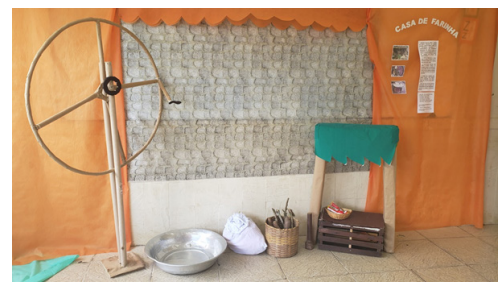

Fotografia: Ana Vaz, 29/11/2019.
Figura 3: Cenário que representa o roçado da lavoura de milho e mandioca.

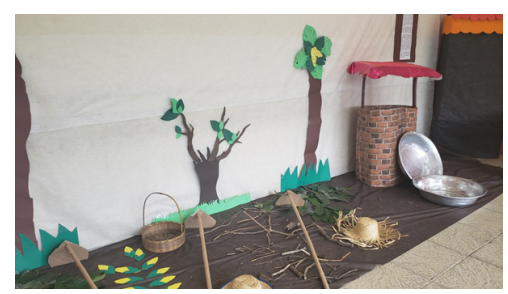

Fotografia: Ana Vaz, 29/11/2019.
Figura 4: Cenário que representa cozinha com fogão de lenha e pilão escavado no tronco de árvore.

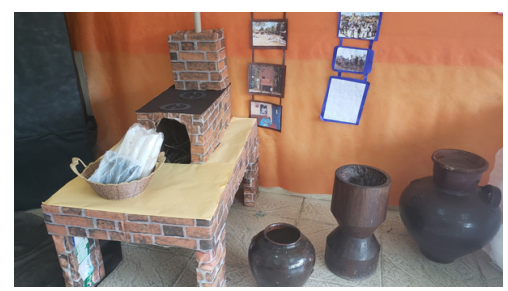

Fotografia: Ana Vaz, 29/11/2019.
Figura 5: Brinquedos produzidos a partir de oficinas de reciclagem.

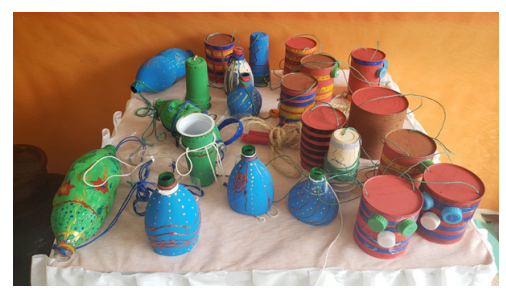

Fotografia: Ana Vaz, 29/11/2019.

Para a construção desses artefatos, os saberes transmitidos oralmente pelas lideranças entrevistadas foram agenciados pelos(as) alunos(as), a partir da proposição da professora Bianca. Posteriormente, os estudantes construíram uma representação que desse conta de visibilizar e valorizar aspectos da cultura local tidos como importantes pelas mestras entrevistadas. A criatividade foi ludicamente exercida para a construção dos brinquedos e dos cenários, e constitui capacidade prática necessária à transformação dos materiais disponíveis em artefatos que atendam às necessidades e contingências encontradas no cotidiano do grupo. Também foi dado destaque aos instrumentos que permitem a obtenção de alimentos e garantem a segurança alimentar da comunidade, como o barco de pesca, o roçado e a casa de farinha. A representação desses instrumentos remete, também, à fartura da colheita, da pesca e da produção da farinha enquanto mote das antigas festas, realizadas à beira da fogueira, onde comida e bebida eram consumidos aos sons dos tambores e de vozes que cantavam os desafios em pontos cifrados e enigmáticos de jongos e cirandas.

A cozinha, a casa de farinha e o fogão de lenha merecem especial atenção devido à importância no cômputo dessa montagem. Nas tradições africanas e afro-brasileiras, o ato de cozinhar é o exemplo 
máximo da potencialidade da transformação por meio da qual se dá vida ao que antes estava morto, usando para tanto os próprios elementos da natureza (fogo, água, ar e terra transmutada pela metalurgia ou cerâmica). Assim, o ato de cozinhar, em sociedades de matriz africana, tende a ser de responsabilidade das mulheres enquanto gesto simbólico do próprio princípio feminino da transformação criadora. Por intermédio dessa culinária, a própria manutenção alimentar do grupo é cotidianamente realizada, por uma cadeia de produção, assim como pelo preparo de alimentos e infusões de ervas para a cura dos males.

Os(as) alunos(as) tiveram, pois, a oportunidade de produzir obras estéticas, realizada a partir do movimento do corpo e da ação das mãos. Os objetos narrados pelas mestras foram transcodificados, representados e reproduzidos a partir de espécie de arte efêmera, tornando-as coisas tangíveis, suportes das memórias que, quando agrupados, passaram a constituir os cenários. Tais suportes promovem a objetivação da própria "cultura" quilombola.

Para que a comunicação com o público pudesse acontecer de forma plena, a turma lançou mão da escrita narrativa e imagética, por meio da qual articularam fotografias e textos impressos para, assim, oferecer aos espectadores diversas informações: sobre as entrevistas realizadas, os moradores da comunidade do Quilombo da Rasa e o processo de pesquisa desenvolvido sob a orientação da professora Bianca. A cada visita que recebiam, as(os) discentes performavam uma pequena encenação de como, segundo as narrativas das mestras, viviam os moradores da Rasa no passado.

Assim, pais, irmãos e demais familiares, distribuídos em grupos pequenos, foram convidados a entrar em cada uma das salas onde estavam montados os cenários e ali as crianças passavam a contar sobre a visita que fizeram às anciãs, explicando como era realizado o trabalho necessário para a própria manutenção do grupo, por meio da pesca com canoa feita pelos próprios residentes com um único grande tronco. Também relataram como os antigos moradores da Rasa sabiam cozinhar e fazer farinha no fogão de lenha, com mandioca e milho, o que garantia a estocagem de comida num momento em que não existia geladeira.

Essa apresentação foi realizada na escola que se abriu ao final do ano letivo para receber a comunidade escolar para visitação, como culminância do projeto da Festa Literária. A construção dos cenários permitiu que os demais docentes também passassem a conhecer aspectos julgados relevantes pelos quilombolas sobre suas formas de organização, sua história, cotidiano, cultura e processos econômicos, num denso processo de comunicação. A montagem da exposição durante o evento literário permitiu que as referências sobre o mundo particular dos quilombolas circulassem no espaço escolar, tornando visíveis ao público - formado por professoras(es), alunos(as) e seus familiares - as representações dos lugares de trabalho e também do interior das casas, espaço privado onde a vida cotidiana desse grupo acontece. Desse modo, as crianças e jovens que participaram da exposição puderam tanto expor, quanto fruir de suas próprias obras estéticas, construídas coletivamente.

Uma vez que os demais docentes pouco saem da escola ao longo do ano letivo, Bianca e sua turma levaram um pouco do quilombo para aquele ambiente. A professora compreende o desafio que é para seus colegas trabalharem com a cultura da comunidade quilombola, tendo em vista que, em sua avaliação, possuem pouco conhecimento sobre a formação dela: 
É muito difícil quem vem de fora, quem não é do bairro da Rasa, conhecer. Porque não tem registro. No YouTube tem uma coisa ou outra de um historiador que veio do Rio de Janeiro e pesquisou. Eu acho que a gente precisa, a comunidade quilombola precisa de um historiador vir, focar, estudar a fundo a história da comunidade. Divulgar essa história, em um site oficial da prefeitura de Búzios, fazer um livro sobre essa história. Assim, teria mais facilidade para o professor ter acesso, porque se eu não conhecesse a dona Uia, dona Eva, a família do meu esposo que é quilombola, eu não saberia de praticamente nada. Saberia algumas coisas que tem em site que, às vezes, nem são verdadeiras, porque quando pergunta aos moradores... O que é preocupante é que os detentores desse conhecimento já estão com a idade bem avançada. E quando eles morrerem? E essa história? Os netos às vezes não sabem, não se interessam. Os filhos sabem pouquinho. Então, vai acabar se perdendo no meio de tudo isso aí (Entrevista com a professora Bianca, 29/11/2019).

Essa percepção impulsionou a necessidade sentida por Bianca de ampliar o alcance das discussões sobre a educação em comunidades quilombolas, a partir de ações que extrapolem os muros da escola e aproveitem o potencial dos processos de educação informal engendrados pelos próprios grupos, portanto, específicos a cada comunidade. A questão da construção da identidade de crianças e jovens, os conflitos, as influências e dúvidas decorrentes desse processo constituem problemáticas que afetam toda uma comunidade e os reflexos disso impactam, sobremaneira, o desenvolvimento das ações pedagógicas no ambiente escolar ${ }^{7}$.

Ainda que de maneira prescritiva, parece oportuno argumentar que o desenvolvimento de uma educação antirracista que, nesse caso, valorize as especificidades do quilombo e o respeito aos quilombolas, precisa levar em consideração os(as) mestres(as), seus(as) anciãos(as) que são guardiões da palavra ancestral, uma vez que se encarregam de transmitir o que foi vivido e o que lhes foi ensinado, preservando as memórias coletivas e os conhecimentos do grupo. É importante frisar que familiares das anciãs apontaram a falta de políticas públicas focalizadas na valorização da cultura local pelo município de Búzios:

Acho que a gente tem que ter um pouquinho mais de apoio. Ali na Rasa a gente não tem uma sede. Na Baía Formosa é mais organizada. Você já viu? Eles têm um quilombo, uma sede. Podem ir lá visitar, participar. Aqui não tem, existe uma casa que é da vovó. Ela está lá deitada o dia todo na cama e fica cheio de gente. É muito difícil. Não tem um espaço para receber os alunos, têm que ficar do lado de fora" (Entrevista com Sandra, 21/11/2019).

A Baía Formosa guarda relações históricas de continuidade geográfica com a Rasa, sendo que pessoas de ambas as comunidades quilombolas mantêm trocas, comércio e relações de parentesco entre si. Interessante verificar que o fato de Baía Formosa possuir infraestrutura física e sede coletiva é acionado como subsídio para compreender o impacto da falta desses espaços coletivos na vida das próprias

\footnotetext{
7 Como destaca Libâneo (2014: 81): “Ao fazer da experiência social concreta dos alunos a própria trama do trabalho pedagógico, sobre a qual se introduz o conteúdo científico das matérias, está-se concebendo o conhecimento como uma atividade inseparável da prática social. A atividade teórica é o processo que, partindo da prática, leva a 'aprender' a realidade objetiva para, em seguida, aplicar o conhecimento adquirido na prática social para transformá-la. A ênfase nos conhecimentos não visa, portanto, o acúmulo de informações, mas uma reelaboração mental que se traduzirá em comportamentos práticos, numa nova perspectiva de ação sobre o mundo social".
} 
pessoas da Rasa, em especial, das anciãs e lideranças comunitárias, que se prontificaram a abrir mão da intimidade de seu lar para abrigar em suas próprias casas ações consideradas importantes para a comunidade, como a desenvolvida por Bianca e seus alunos.

\section{Aplicação do artigo 26A da LBD desde a perspectiva nativa}

As escolas brasileiras são instituições herdeiras dos princípios e valores que constituíram e legitimaram as sociedades ocidentais urbanas e modernas, pautados pelo saber técnico e científico, bem como pela ideia de progresso e desenvolvimento, em estados nacionais como forma de organização política.

Historicamente, o saber científico é aquele que amplamente legitima os currículos escolares, que acabam por neutralizar e não discutir aspectos históricos, políticos, econômicos, ideológicos da produção da própria ciência, pouco apresentando outras formas de construção e transmissão de conhecimentos presentes nas mais distintas sociedades e culturas. Esse processo no Brasil acontece desde a assinatura do Manifesto dos Pioneiros da Escola Nova, lançado em 1932. Segundo Antonacci (2016:246): “o chão da escola adequava-se, graças a métodos e equipamentos técnico-científicos, aos interesses industriais em relação à seleção e formação racional de um trabalhador nacional, nos marcos do Estado Novo".

Ao longo dos anos 2000, durante o Governo do Presidente Luiz Inácio Lula da Silva (Partido dos Trabalhadores), aconteceu um particular reconhecimento político de movimentos sociais mobilizados para reivindicar e defender o direito de pleno acesso à educação, desdobrando-se na elaboração das leis 10.639/2003 e 11.645/2008, supramencionadas. Enraizadas em lutas dos movimentos negros e indígenas, universidades, projetos e programas de capacitação, treinamento e atualização pedagógica foram interpelados, chamados a lembrar e a embasar docentes com habilidades para reverter e repensar lacunas de nossas histórias. Emergem, assim, abordagens que se ocupam de ações e intervenções de povos europeus, africanos, afro-diaspóricos, ameríndios, conforme perfil dessas leis fundamentais para descolonização da história do Brasil, de grades curriculares e de práticas pedagógicas discursivas (Antonacci, 2016).

No cotidiano escolar, as culturas híbridas de matrizes orais e performáticas - em geral de tradições afro-brasileiras, ameríndias e populares - foram historicamente interditadas, silenciadas, banalizadas, adulteradas, folclorizadas e deslocadas pela modernidade e seus recursos técnico-pedagógicos, pautados na centralidade do letramento e da ciência tecnológica para a validação de saberes. Tal choque epistemológico e civilizacional foi denominado por Mignolo (2005) de "epistemicídio", enquanto processo que acontece em nível micropolítico, dentro de cada sala de aula, sob a chancela do currículo e da ação de docentes induzidos a assumir o papel estrutural da missão civilizadora do Ocidente, a partir de releituras e da atualização de táticas e estratégias de colonização e adestramento da mente e do corpo, sendo estas muito semelhantes às empregadas no passado escravocrata.

A crítica decolonial permite a compreensão das consequências políticas desses processos de longa duração. Os estudantes apresentam desinteresse e desestímulo ao se depararem com conteúdos e práticas de aprendizagem distantes de seu cotidiano cultural, bem como dos seus interesses imediatos 
para lidar com contingências que afligem e expõem marcas deixadas pela violência e desigualdade étnico-raciais. Estas são causas, muitas das vezes, da não permanência e do abandono da sala de aula por falta de motivação relativa aos conteúdos da aprendizagem e pela incapacidade da educação oferecer a segurança de projeção de um futuro pleno e digno, seguindo seu curso sem a construção de alternativas às formas e aos conteúdos eurocêntricos de transmissão de conhecimentos.

A experiência de contar e ouvir histórias faz parte do processo de construção do saber no espaço escolar, sendo um importante instrumento pedagógico interdisciplinar de valorização da identidade e do desenvolvimento do sentimento de pertencimento. Contar e ouvir experiências de vida também é um meio de registro legítimo da história. Isso porque coloca discentes e seus familiares como agentes, protagonistas da construção do seu próprio conhecimento. Além de proporcionar um diálogo entre as vivências de gerações, grupos e pessoas distintas, a valorização das tradições orais permite o compartilhamento de ideias e sentimentos, amenizando o estranhamento das diferenças existentes entre as comunidades e os sujeitos.

Os mestres e lideranças da cultura popular podem ser caracterizados como atores que se submeteram a intenso treinamento ativo e que, ao longo de sua vida, conquistaram o domínio do exercício da palavra e do emprego eficiente dos conhecimentos tradicionais. Por meio de suas ações e de seus ensinamentos, acontece a manutenção dos laços comunitários, geralmente a partir de ações micropolíticas de resistência, resiliência e transmissão das memórias e narrativas contadas sobre a trajetória específica de seus grupos ao longo do tempo.

A valorização dada aos registros escritos na educação escolar pode, paradoxalmente, se tornar um empecilho para a compreensão da importância dos conhecimentos que são construídos e compartilhados nas comunidades tradicionais por meio da oralidade. Além do enfrentamento de dilemas e desafios de ordem política, religiosa, ética e epistemológica, essas comunidades ainda esbarram em dificuldades que barram a inclusão de suas memórias, sua história, cultura e seus valores nas escolas, uma vez que estas têm desenvolvido um currículo que tende a reforçar as desigualdades, assimetrias epistemológicas e sociais.

No caso das ações desenvolvidas por Bianca, foi possível reconhecer alternativas que lançam mão do currículo escolar, em especial do Artigo 26A da LDB, para valorizar as formas tradicionais de transmissão de saberes, valores, histórias de vida e experiências que são peculiares à comunidade quilombola em que a escola está localizada. Pudemos compreender a atenção dessa professora para questões sensíveis relativas aos conflitos e desigualdades de oportunidades, frutos de formas de violência étnico-racial que constituem o contexto de vivência de seu alunado. Para tanto, foi necessário que ela considerasse a história da comunidade negra de Rasa contrastada tanto ao processo de colonização política, econômica, social e epistêmica de africanos e seus descendentes no Brasil, quanto à resultante diversidade cultural brasileira.

Bianca não tratou de promover a rivalidade entre distintos saberes, como se um se sobrepusesse ao outro, mas alertou a turma e a comunidade escolar envolvente para a necessidade de promover diálogos entre os conteúdos pré-estabelecidos pelo currículo escolar e os saberes tradicionais. O projeto desenvolvido pela professora Bianca, sua turma e as anciãs do quilombo atende às manifestações das 
diferenças e aos anseios de construção de um futuro digno, por meio da promoção do diálogo simétrico entre saberes, condição fundamental para a reelaboração de estratégias endógenas que podem proporcionar a sustentabilidade da vida, bem como a cidadania plena, da própria comunidade.

Ana Carolina de Sousa Vaz é Doutoranda em Politicas Sociais pela Universidade Estadual do Norte Fluminense Darcy Ribeiro (UENF), sob financiamento da Fundação de Amparo à Pesquisa do Estado do Rio de Janeiro (FAPERJ) e Mestra em Cognição e Linguagem também pela UENF.

\section{Lilian Sagio Cezar é Doutora em Ciência Social (Antropologia Social) pela Universidade de São Paulo (USP) e Professora Associada da Universidade Es- tadual do Norte Fluminense Darcy Ribeiro (UENF).}

\section{REFERÊNCIAS}

Accioli, N. T. (2012). José Gonçalves da Silva à Nação Brasileira: o tráfico ilegal de escravos no antigo Cabo Frio. Niterói: FUNARJ/Imprensa Oficial. Disponível em: https://www.bn.gov.br/sites/ default/files/documentos/producao/pesquisa/jose-goncalves-silva-nacao-brasileira-trafico-ilegal// nilma_accioli_pnap.pdf

Accioli, N. T. (2018). Pagando dia para morar. Considerações sobre a ocupação Quilombola na Região dos Lagos - Rio de Janeiro, Brasil. Rev. Diálogos Mercosur, 5, 22-37. Disponível em: http:// www.revistadialogosenmercosur.com/gallery/2\%20oficial\%20articulo\%20num\%205\%20jul\%20 dic\%202018diamersul.pdf

Almeida, B. C. de. (2015). Entre o passado e o presente, entre História e memória: a Rasa e seus entre-lugares. Revista Escrita da História, 2(4), 1-33. Disponível em: http://www.escritadahistoria. com/revista/index.php/reh/article/view/38

Antonacci, M. A. (2016). Artes da memória de povos em diáspora: História e Pedagogia em "condições de enunciação" Fronteiras: Revista de História, 18(31), 244-256. Disponível em: https://ojs. ufgd.edu.br/index.php/FRONTEIRAS/article/view/5466

Arruti, J. M. (2017). Conceitos, normas e números: uma introdução à Educação Escolar Quilombola. Revista Contemporânea de Educação, 12(23), 107-142. Disponível em: https://revistas.ufrj.br/index. $\mathrm{php} / \mathrm{rce} /$ article/view/3454/7619 
Barth, F. (1998). Grupos étnicos e suas fronteiras. In: P. Poutignat \& J. Streiff-Fenart. Teorias da etnicidade: seguido de grupos étnicos e suas fronteiras de Fredrik Barth (pp. 185-228). São Paulo: Editora Fundação da Unesp.

Bastide, R. (1960). As religiōes africanas no Brasil. Contribuição a uma sociologia das interpretações de civilizações. vol. 1 e 2. São Paulo: Ed. Universidade de São Paulo.

Brasil. (2003a). Lei no 10.639, de 09 de janeiro de 2003. Brasília. Disponível em: http://www.planalto.gov.br/ccivil_03/leis/2003/110.639.htm

Brasil. (2003b). Decreto no 4.887, de 20 de novembro de 2003. Brasília. Disponível em: http://www. planalto.gov.br/ccivil_03/decreto/2003/d4887.htm\#: :text=DECRETO\%20N\%C2\%BA\%20 4.887\%2C\%20DE\%2020,Ato\%20das\%20Disposi\%C3\%A7\%C3\%B5es\%20Constitucionais\%20 Transit\%C3\%B3rias

Brasil. (2008). Lei no 11.645, de 10 de março de 2008. Disponível em: http://www.planalto.gov.br/ ccivil_03/_ato2007-2010/2008/lei/111645.html

Brasil. (2010a). Conselho Nacional de Educação (CNE); Câmara de Educação Básica (CEB). Diretrizes Curriculares Nacionais para a Educação Básica. Brasília: CNE/CEB.

Brasil. (2010b). Lei de Diretrizes e Bases da Educação Nacional: Lei no 9.394, de 20 de dezembro de 1996, que estabelece as diretrizes e bases da educação nacional. $5^{\text {a }}$ ed. Brasília: Câmara dos Deputados, Coordenação Edições Câmara.

Brasil. (2012). Conselho Nacional de Educação (CNE); Câmara de Educação Básica (CEB). Resolução no 8, de 20 de novembro de 2012: Diretrizes Curriculares Nacionais para a Educação Escolar Quilombola na Educação Básica. Brasília: CNE/CEB.

Brasil. (2013). Secretaria de Políticas de Promoção da Igualdade Racial. Guia de Políticas Públicas para Comunidades Quilombolas. Programa Brasil Quilombola. Disponível em: https://www.gov.br/ $\mathrm{mdh} / \mathrm{pt}$-br/centrais-de-conteudo/igualdade-racial/guia-de-politicas-publicas-para-comunidades-quilombolas/view

Carneiro da Cunha, M., \& Almeida, M. W. B. (2001). Populações tradicionais e conservação ambiental. In: J. P. Capobianco (org). Biodiversidade na Amazônia Brasileira (pp. 147-163). São Paulo: Estação Liberdade/ Instituto Socioambiental.

Carvalho, B. H. C. P. de. (2015). Comunidade Remanescente de Quilombo da Rasa: uma abordagem das relações de identificação étnica e religiosa (Dissertação de Mestrado). Universidade Estadual do Norte Fluminense Darcy Ribeiro, Campos dos Goytacazes. Disponível em: https://uenf.br/posgraduacao/sociologia-politica/wp-content/uploads/sites/9/2013/03/Barbara.pdf 
Conaq. s/d. Coordenação Nacional de Articulação das Comunidades Negras Rurais Quilombolas. Disponível em: http://conaq.org.br/quem-somos/

Freinet, C. (1966). Para uma Escola do Povo. São Paulo: Martins Fontes.

Geertz, C. (1989). A interpretação das culturas. Rio de Janeiro: Guanabara.

Gusmão, N. M. M. de. (1999). Linguagem, cultura e alteridade: imagens do outro. Cadernos de Pesquisa, 107, 41-78. https://doi.org/10.1590/S0100-15741999000200002

Halbwachs, M. (1990). A memória coletiva. São Paulo: Vértice.

Hampaté Bâ, A. (2010). A Tradição Viva. In: J. Ki-Zerbo (org.) História Geral da África I: Metodologia e Pré-História da África (pp. 167-212). Brasília: UNESCO.

Holanda, S. B. de (org). (1960). História geral da civilização brasileira. São Paulo: Difusão Europeia do Livro, Tomo I.

IBGE - Instituto Brasileiro de Geografia e Estatística. (2017). Censo demográfico - Armação dos Búzios. Disponível em: https://www.ibge.gov.br/cidades-e-estados/rj/armacao-dos-buzios.html

INCRA. (2017). Instituto Nacional de Colonização e Reforma Agrária. Brasília. Disponível em: http://www.incra.gov.br/sites/default/files/relatorios_tecnicos_de_identificacao_e_delimitacao_ rtid_publicados_em_2017_pelo_incra_0.pdf

Ingold, T. (2000). The percepption of the environment. Essays in livelihood, dwelling and skill. Londres: Routledge.

Leite, I. B. (2000). Os quilombos no Brasil: questões conceituais e normativas. Etnográfica, IV(2), 333-354. Disponível em: http://ceas.iscte.pt/etnografica/docs/vol_04/N2/Vol_iv_N2_333-354.pdf

Libâneo, J. C. (2014). Democratização da escola pública: a pedagogia crítico-social dos conteúdos. $28^{a}$ ed. São Paulo: Edições Loyola.

Maldonado-Torres, N. (2016). Transdisciplinaridade e decolonialidade. Sociedade e Estado, 31(1), 75-97. http://dx.doi.org/10.1590/S0102-69922016000100005

Mignolo, W. D. (2005). A colonialidade de cabo a rabo: o hemisfério ocidental no horizonte conceitual da modernidade. In: A colonialidade do saber: eurocentrismo e ciências sociais. Perspectivas latino-americanas (pp. 71-103). Buenos Aires: CLACSO.

Munanga, K. (org.) (2005). Superando o racismo na escola. $2^{a}$ ed. rev. Brasília: Ministério da Educação, Secretaria de Educação Continuada, Alfabetização e Diversidade. 
Munanga, K., \& Gomes, N. L. (2006). O Negro no Brasil de Hoje. São Paulo: Global.

Prandi, R. (2000). De africano a afro-brasileiro: etnia, identidade, religião. Revista USP, 46, 52-65. https://doi.org/10.11606/issn.2316-9036.v0i46p52-65

O’Dwyer, E. C. (2007). Terras de quilombo: identidade étnica e os caminhos do reconhecimento. TOMO, 10, 43-58. https://doi.org/10.21669/tomo.v0i11.446

Reis, M. C. G. (2017). Mulheres, negras e professoras: suas histórias de vida. Campos dos Goytacazes: Brasil Multicultural.

Rocha, R. M. C. (2011). A Pedagogia da Tradição: as dimensões do ensinar e do aprender no cotidiano das comunidades afro-brasileiras. XI Congresso Luso Afro Brasileiro de Ciências Sociais - UFBA. Salvador. Disponível em: http://revista.fumec.br/index.php/paideia/article/view/1308/889

Santos, L. L. C. P. (2001). Dilemas e perspectivas na relação entre ensino e pesquisa. In: M. André (org.). O papel da pesquisa na formação e na prática de professores (pp. 11-25). Campinas: Papirus.

Secretaria Municipal de Educação, Ciência e Tecnologia. (2019a). Referencial Curricular de Armação dos Búzios. Armação dos Búzios.

Secretaria Municipal de Educação, Ciência e Tecnologia. (2019b). Projeto da Festa Literária Búzios Palavra que Encanta. Armação dos Búzios.

Silva, V. G. da. (2007) Neopentecostalismo e religiões afro-brasileiras: significados do ataque aos símbolos da herança religiosa africana no Brasil contemporâneo. Mana, 13(1), 207-236. http://dx.doi. org/10.1590/S0104-93132007000100008

Spillmann, C. V. (2010). Implantação de coleta seletiva em meios de hospedagem em municípios turísticos: caso de Armação dos Búzios/RJ (Dissertação de Mestrado). Pontifícia Universidade Católica do Rio de Janeiro, Rio de Janeiro. Disponível em: http://bdtd.ibict.br/vufind/Record/PUC_RIO-1_ 0840f48ef04ac11109a0a0672a7b639d

Vaz, A. C. S. (2015). Juventude e Identidade: o sentimento de pertencimento de alunos do bairro da Rasa em Armação dos Búzios/RJ (Dissertação de Mestrado). Universidade Estadual do Norte Fluminense Darcy Ribeiro, Campos dos Goytacazes. Disponível em: http://www.pgcl.uenf.br/arquivos/ dissertacaocarolina_030920191430.pdf

Xavier, M. A. P. (2006). Búzios: estética, poder e território (Dissertação de Mestrado). Universidade Federal do Rio de Janeiro, Rio de Janeiro. 


\title{
TRADIÇÃo ORAL, CONSTRUÇÃo DE DIÁlOGO E CONHECIMENTO NA COMUNIDADE QUILOMBOLA DA RASA
}

Resumo: O presente artigo é resultado de estudo de caso que tematiza as ações de educação formal dedicadas à História e Cultura Afro-Brasileira e Indígena em uma escola localizada na comunidade remanescente de quilombo da Rasa, no município de Armação dos Búzios (RJ). Por meio da articulação da Antropologia e da Pedagogia, realizamos pesquisa empregando entrevistas semiestruturadas e abertas realizadas com professoras(es), gestoras(es) escolares e familiares de alunas/os que são quilombolas. Posteriormente, elegemos proceder investida etnográfica acerca das ações desenvolvidas por uma professora, com seus estudantes e a comunidade, com vistas à participação da turma na Festa Literária promovida pelo governo do município. Buscamos assim compreender as potencialidades e os desafios da abordagem dos conteúdos previstos nas leis 10.639/2003 e 11.645/2008. Discutimos, ainda, por meio da crítica decolonial, o papel da escola diante de sociedades cujos meios privilegiados de transmissão de conhecimentos são a tradição oral e a memória coletiva.

Palavras-chave: Educação; Relações étnico-raciais; Quilombo; Tradição Oral; Identidade.

\section{ORAL TRADITION, DIALOGUE BUILDING, AND KNOWLEDGE IN THE RASA QUILOMBOLA COMMUNITY}

\begin{abstract}
This article is the result of a case study that problematizes formal education actions focused on Afro-Brazilian and Indigenous History and Culture at a school located in the remaining community of the Quilombo da Rasa, in the municipality of Armação dos Búzios (RJ), Brazil. Through the articulation of Anthropology and Pedagogy, we researched by semi-structured and open interviews with teachers, school managers, and family members of quilombola students. Subsequently, we chose to carry out an ethnographic effort on the actions developed by a teacher with students and the community to participate in Literary Festival, promoted by the local government. In this way, we tried to understand the potential and challenges of approaching the contents provided in Laws 10.639 / 2003 and 11.645 / 2008. Through decolonial criticism, we also discussed the role of the school in the face of societies whose privileged means of transmitting knowledge are oral tradition and collective memory.
\end{abstract} Keywords: Education; Ethnic-racial relations; Quilombo; Oral Tradition; Identity.

RECEBIDO: $31 / 05 / 2020$

ACEITO: 07/06/2021 